\title{
БОЖИЋ КОД СРБА У СОКОЛОВЦУ У РУМУНИЈИ
}

У јуну месецу 2019. године, екипа Етнографског института САНУ, обавила је истраживања у три села у Румунији - Соколовац, Луговет и Златица. Разговор је вођен са мештанима поменутих села на теме: Крсна слава, Божић и свадбени обичаји. У раду се представљају сазнања о обичајима током божићног празновања код Срба у Соколовцу.

Кључне речи: Божић, Срби, теренска истраживања, Соколовац, Румунија.

У јуну месецу 2019. године боравила сам неколико дана у Румунији (област Пољадија) где сам обавила истраживања на тему Крсна слава, Божић и свадбени обичаји. Истраживања су рађена у оквиру пројекта: Истражсивање историје и културе Срба у Румунији. Организатор истраживања, као и претходних година $(2016,2017,2018)$, био је Центар за научна истраживања и културу Срба у Румунији (Темишвар). Током истраживања, екипа Етнографског института САНУ посетила је три села - Соколовац, Луговет и Златица, у којима је сваки истраживач обавио разговор са по неколико мештана. У овом раду се представља обичајно-обредна пракса током божићног празновања код Срба у Соколовцу.

$$
* * *
$$

Као што је у претходним радовима већ наглашено (Ивановић Баришић 2018, 89-98; Ивановић Баришић 2019, 129-144), Божић представља централни празник у годишњем (календарском) циклусу народних светковина. Такође је, осим у народној, један од најважнијих празника и у хришћанској традицији. Хришћанска традиција празновање Божића повезује с рођењем Христа. Због значаја који му се придаје Хришћанство Божић издваја из корпуса осталих празника календарског циклуса. С друге стране, божићно празновање поклапа се са временом зимског солстиција па се у народној традиција повезује с најмањом сунчевом активношћу.

\footnotetext{
${ }^{1}$ milina.barisic@ei.sanu.ac.rs

${ }^{2}$ Рад је резултат истраживања на пројекту: Истраживање културе и историје Срба у Румунији. Реализацију пројекта је финансирао Центар за научна истраживања и културу Срба у Румунији при Савезу Срба у Румунији. Рад је делом резултат рада и на пројекту 177028 који је у целости финансирало Министарство просвете, науке и технолошког развоја Републике Србије.
} 
„Због свог места у празновању и важности која му се придаје у народној и хришћанској традицији, божићни празници могу се посматрати неком врстом нулте тачке почетка у кружном годишњем кретању и празновању“ (Ивановић Баришић, 2018: 90).

Божић се празнује три дана. Осим на сам дан празника, обичаји се обављају и уочи самог Божића - на Светог Игњата и на Бадње вече, као и после Божића - на Нову годину. На основу исказа добијених у разговорима са мештанима истраживаних села сазнаје се да је празнични садржај на Бадњи дан и Божић код Срба у овом делу румунског Баната очуван у прилично редукованој форми. О обичајима, а ради се о казивачима са којима сам ја водила разговор, постоји недовољно очувано сећање о комплетним обичајима који су некад постојали мада су и о садашњој обичајној пракси искази прилично непотпуни да би се на основу њих добио потпунији увид у форму и функцију обичајно-обредне праксе у српској заједници овог простора у ближој, а поготово даљој прошлости.

Празновање Божића и данас подразумева:

1. Празнике који му претходе;

2. Тродневно прослављање Божића;

3. Празнике који се празнују после Божића.

У овом раду представљају се божићни обичаји сагледани кроз податке добијене у разговорима који су вођени током истраживања у селу Соколовац. ${ }^{3}$ Према теренским сазнањима, празници који претходе празновању Божића су се у значајној мери изобичајили. У овом случају свакако треба имати у виду чињеницу да ранијих етнолошких истраживања скоро да није било па је због тога стручно-научна заједница готово у потпуности ускраћена у увид у ранију обичајну праксу не само у Пољадији, него на читавом простору Румуније где су Срби раније живели или живе још увек, да би се могло са сигурношћу тврдити какве су редукције и промене наступиле у садржају божићног, а вероватно и осталог, празничног садржаја. Оно што се према исказима може закључити јесте да се обичаји одржавају много мање у односу на раније деценије на шта ће делом указати и овде издвојен и представљен емпиријски материјал, тачније делови разговора који су обављени током боравка на терену у овом делу Румуније.

Божићне покладе. Божићно празновање је у прошлости код српског народа започињало божићним покладама после којих је наступао божићни пост. У садашњем времену се у Соколовцу не зна за ове покладе, нити постоји сећање да су оне у ранијем времену биле обележаване.

Биле су само ускршъе Покладе.

\footnotetext{
${ }^{3}$ Сазнања о божићним обичајима у селима Луговет и Златица биће представљена у другом раду.
} 
Божићни пост. За божићни пост се зна, али се он у садашњем времену врло ретко поштује у целости. Углавном се пости седам дана пред Божић због причеста или најчешће само Бадњи дан.

О посту. Постио се пост, али већина у то време коље (...), неки посту да се причесту треба да постиш осам дана, после дијеш у иркву да се причестиш, сад... И раније се није постио цео пост? Не, осам дана се постило, било је пре, се мало и постило, било, старији људи, било се месиле проје, па су јели проје, па ием - тај пекмез озгоре, па се јело, сад коће некога младога да тера да једе пекмез са проје, неће то нико да ради. Једу овај лебаи мек, па кад извучеш из ъега... све извучеш... значи, постио се пос. Причешћивало се после тог поста? Ишло на причест? Да, је се ишло. Овде у вашу цркву? У нашу иркву.

Храна. Они који посте шта једу - проју, пекмез? Шта још? Проју, пекмез, хлеб, ... не једу вако сира... купуса киселога, расола било. То све јели ьуди - бил бели и ирвени, лепи. А сад код нас неће, ко ће да је сад расола? Ко ће да је качамак са расолом? Качамак са расолом? То било, то се јело, то кад је пос. Кад се постило јел то било и на уљу или је било само на води? На уље било, а било и на води.

Целодневни пост. Да ли је било да се на Бадњи дан није цео дан ништа јело до вечере? Било, било, није се јело. Како се то звало? Па незнам, каже ко не је тај може да вата тичиће ... незнам као се звало, није се јело. И сад неко не је на Велики петак, не је (Цео дан?) цео дан.

$$
* * *
$$

Света Варвара. Дан у који се празнује Света Варвара обично се у српском народу назива „Варица“. Са Варваром је започињао зимски циклус празновања. На овај дан су у прошлости постојали и одређени обичаји а најпознатији је кување житне каше. Међутим, у селима у Пољадији, па и Соколовцу, у којима су вршена истраживања не зна се за овај празник нити за обичај кувања житне каше.

Варица. На Свету Варвару, јел било да се кува неко жито, да се прави варица? Није било, овде код нас се само кољиво прави за задушнице.

$$
* * *
$$

Свети Игњат. На овај празник почиње божићно празновање, али и упућивање честитки за свеукупни просперитет породице и њених чланова и свега што је неопходно за напредак домаћинства. Ове жеље кући упућују деца која пилу у шпорету са дрветом које називају шумарица. Осим на Игњата пила се још на Бадњи дан и први дан Божића. Других обичаја, по казивању, није било. 
Полаженик. На Светог Игњата, то је другог јануара, да ли је било неких обичаја? Па, било, да деца пилу мало. Узму дрво једно, како ћу да вам кажем, дрво бадњак које ће да гураду у шпорет. Значи они су били нека врста полаженика? Јесте, такој било код нас. Децуа седну тамо код тога и вичу... Где седну? Код шпорета и вичу: пилиће, кокошке, јагањаца, оваца, жсиота и здравља и све што год има у кући. И после тако кад хоће да се дигну баба их дигне, а не они сами и онда им да леј и онда их подигне. Јел то неко дете из комшилука? Не, не, из куће, то је било пре тако. Ако дође неко са стране мора тај да... Ако неко дође пре детета онда он мора... Јесте... Он дође и сам седне испред шпорета и има тај бадњачић... То дрво...

Бадњак. Од чега је обично? Од шумарице, тако смо ми звали, то тај, што кажу бадњак. То је на Бадњи дан или на Игњатов дан? На Игњатов дан се пили и на Бадюи дан се пили и на први дан Божића! Кад се тај бадњак којим се пили, шумарице како кажете, кад се он доноси у кућу, одакле? Па добро, прво смо секли... то се секло дрво у планину па се остави то... Кад се секу дрва у планину остави се за то? Jecme. Значи није се ишло пред празник да се сече? Иило се сад за бадюак. А раније се није ишло за бадњак, него... Се сече, па туј било код нас иума па се секло. Нисмо никад купили дрва, ишли па секли тамо горе у иуму, а сад треба да купујемо све, шта да радимо?

Полаженик. Значи то је било на Игњатов дан, он дође испред шпорета и пили, онда га ви узмете и подигнете! Jecme. Да ли га огрћете нечим? He, не, стављамо жита и кукуруза. Кад седне ту поспете га житом и кукурузом? Узмемо решето што се сејало брашно и ту ставимо жита и кукуруза и стављамо преко юега и то остављамо и на први дан Божића и на Бадюи дан ујутру то сипамо.

Значи то се сито напуни... Не пуно баш... Стави се у њега и ту стоји до Божића да се обави све што треба са тим житом. И после на Бадюи дан ту се стави колач на то, што се меси за Божић, се пререже и ондак смо, боже шта беше?... на Бадюи дан смо месили законе... Јел било нешто да се радило са кокошкама, да су се храниле? Не, не. Није ништа, само пилање. Јел то радиле најстарије дете или...? Могу сви. Могу сви и девојчице и дечаци? Сви, сви.

$$
* * *
$$

Туциндан. За овај празник се не зна, заправо се говорило да не постоје никакве посебне радње које би дан издвајале од осталих. Ипак, забележено је једно казивање да су жене на овај дан „затварале“ маказе да вуци не би јели стоку, али није добијен податак до када се не употребљавају.

Јел било нешто на Туциндан да се радило? Не знам. ... Ја знам то је пре тако било једна баба,... који су имали козе, овце по планини - од Ту- 
циинога дана се затвору маказе, не знам до којуга дана тамо ... посе се не отвараду да не једу вуции овиее. То је било. Знао народ све. Моја мама знала ког дана пада киша ће бидне родна година. А ми не знамо сада ништа. Заборавили смо.

Јел било да се деца нису тукла на Туциндан? Нuје. Ни незнаду кад је Туичиндан.

$$
* * *
$$

Бадњи дан. На Бадњи дан се врше припреме за свечано прослављање Божића. На овај дан посте и они који не посте читав пост. Још је увек појединцима у обичају да држе целодневни пост без јела и пића. Најважније обредно-обичајне радње су: мешење обредних хлебова, обичаји са бадњаком и сламом, бадња вечера, колиндање, кићење јелке, идење на гробље.

Шта се радило на Бадњи дан? Пекли су се колачи, божићни и бадњедански, спремала се храна - бадњеданска вечера! Шта се спремало - на Бадњи дан да ли се спремао ручак или вечера? Вечера (Вечера?), вечера - пребранац, супа или чорба рибња, пиренач, обавезно рибе пржене. Значи, од хране се спремала рибља чорба, пребранац, риба сува и свежа,... Јел се спремало нешто слатко - нешто од колача, штрудла, или? Штрудле се правиле и крофне мало. Није се правило вако... (Крофне без јаја), без јаја. Јел било воћа неког? (Како?) Јел било сувих шљива, јабука? Па било, то смо пекли некад, то смо сушили некад кад смо имали, некад, лети. ... А сад има да се купи. То спрему све, ставе ту и кикирики, ораси се спрему, да дођу децуа да вичу ораси се даје, бомбоне се даје,...

- Обредни хлебови. Месе се различити фигурални хлебови на Бадњи дан, а намењени су члановима породице, стоци и плодности поља. Мешење и печење обредних колача - ,закона“ задатак је домаћице. Божићни колачи се израђују од тзв. киселог теста - чистог пшеничног брашна уз додатак квасца. Прво се израђује колач ,здравље“ и божићни колач. Домаћице су месиле и већи број фигуралних хлебова који су за породицу били важни јер су представљали срећу и здравље њених укућана, затим жељу за богатством у домаћој стоци. Дакле, ,закони“ су представљали кућу, виноград, стоку, а праве се такође и буздован, шака, кика и др.

Закони. Се месили закони на Бадюи дан - колико мушкараца имамо у кући толико шаке, колико девојака има у кућу оплетемо кике. Тако је мој отач радио, од свакога кад се кувало јело тамо се ставило у чинију по једно. Није се све секло. И здравље и буздован и свиње и краве и виноград и све то, што год си имо... Јел био колач намењен кући? Да. Како се звао? Чесница... Кажите ми здравље колач како је изгледао? Па, здравље колач се тако умеси и исече. Јел био округао, или? Округао, и тако све се исече, и тако мало се посоли и се мало намаже... Чиме? Неки пут само с јајетом, неки пут само 
с водом! Кад се здравље једе? Па, на Бадюи дан. Ако је Бадњи дан постан, како онда јаје? E па сад, неки пут ставимо оно, па се једе и исече на Божић. Кад се прави чесница мора нешто да има, па после се пререже колач. А буздован зашто се правио? Па правио се..., тако треба, мушкарициа буздован да се прави... Значи, били су намењени стоци, намењени за њиве, за виноград, за мушке, за женске, за кућу, а здравље је било за? За све.

Божићни колач. За све? А јел се правио посебан колач који се секо на Божић? Јесте. Како сте га звали? Како је изгледао? Па, божићни колач. Јел се он украшавао нечим одозго? Па јопет тако... Исто као и славски колач, јел имао ружицу или нешто? Па имао је тако сецкану, као крс. Исто је био округао? Јесте. А, на средини шта се ставља? Све се стави тако жита, да бидне тако као - ми кажемо кита. Кад се секо тај колач јел се та ружица вадила и остављала у кући, или не? Па, стави се, некад се поједе ома, а оно кад стоји ко ће да је..., прашина пада и све... па се потопи живина да noje... Ти колачи, ти хлебови, јел се сви начињу на Божић [грешка - мисли се на Бадњи дан] и једу на Бадњи дан или, или неки остају за сутрадан, за Божић? Не, па то се после једу на Божић, тај хлеб, али то је - како ћу да вам кажем, се једу на Бадюидан увече, мој отаи је секо од сваког по један залогај, тако... Јел се сече ножем или се кида? Ножем, није се кидало...

Божићни хлебови. Хлебове домаћица меси, јел тако? Јесте. Кад их меси? Ујутру... све ујутру... а сад месу кад стигну и онда ставе у шпорет да се испече. Са којом водом су се месили ти божићни хлебови? Па с обичном.

Ови хлепчићи који се намењују стоци - да ли они имитирају овцу...? Као овцуа, пиле... Пиле оправимо тако - па га упилимо (нејасно) тако, и ондак ту му глава, и ондак му сас житом му забодемо два ока и направимо онако мало ... ту је пиле, оној је свиња, оној ... виноград се стави онако чоте на тој... А колач, као кућа? Шта се ту стави горе - кућа па се ставе прозори врата, јел има да се ставе? Или се само прави колач као кућа? Само колач. Само колач као кућа? Пос се прави чесница. То је сутрадан на Божић?

Вино. Значи, рекли смо на Игњатов дан да се пила и то остаје на Бадњи дан и ту, на Бадњи дан се ништа од дрвета не уноси, то је... Кад се пререже колач на Божић ондак се узме сито са житом и та чаша вина ито се пререзо колач и иде тамо газдарица (нејасно) и попије за здравље...

- Бадњак. У Соколовцу су са шумарицом (бадњак?) пилали ватру на Светог Игњатија, Бадњи дан и први да Божића. Сада се углавном у свим селима у порти цркве пали заједнички бадњак. Присутни од њега узимају гранчице доносе у кућу где стоји извесно време или до следећег Божића када га спаљују у шпорету.

Кућни и црквени бадњак. Кад се тај бадњак (или шумарица како кажете) доноси у кућу, ко га доноси, одакле? Па добро, првој смо секли и било 
то. И за Бадюидан сад и опет су били, билиду сечу ту исечу и донесу то, бадюак увече. Значи ... Па то се секу дрва у планину, па се остави то. А, то кад се исеку дрва у планину то се остави, то се остави за то!... Значи није се ишло пред празник да се сече него се... Не пред празник! Него, иило се сад за бадњак, сад иду за бадњак. За бадњак? А раније се није ишло за бадњак него се... Него се сече. Па то је било код нас шума, ту смо секли, никад нисмо купили дрва, иили смо ту секли, секли тамо горе у планину. Сад треба да купујемо све. Шта да радимо!

А овај комад дрвета кад се пилао - како зовете то дрво? .... Јел то бадњак или како га зовете? Па није то бадюак, ми смо звали иумарице... Шумарица, е сад где она стоји до Божића да ли она стоји поред шпорета, поред иконе или буде напољу па се унесе са сламом? Бадњак (Да тај бадњак). Па бадюак се запали напољу. Бадњак се запали напољу, не унесете га у кућу него га напољу палите? Па нешто мало ставимо у кућу нешто у ватру. Ватра се запали и све се изгори (На дворишту?) На дворишту. Па колики буде тај бадњак? Па има неки пут и већи. Јел се од тог бадњака узима нешто да се унесе у кућу? Jесте од тог бадњака. Од тог бадњака шта се унесе? Гранчица, па ене нам стоји у вазу тамо, (...) донели деца кад су била тамо у цркву они донели... То се пали испред цркве бадњак? Да, испред цркве. Испред цркве се пали, то се доноси један заједнички пали се испред цркве? Да, да.

А и свака кућа пали свој бадњак или само испред цркве? Нема саде. Мој син иде и још неко с юим тамо поред пута исечу бадюак, идеду за бадюак да донесу га да запалу. И запале. Где - испред куће? Ty, на двориште, не на иементу, него на земљу. И ту га само ставе? Јел има да попију неко пиће, или? Ракије вруће се стави да се греје. А они не волу сад, то је шећер, није здраво, а ми смо пре знали то на сваки светак-на Богојављење, на јутрење, и на фруштук и на ручак вруће ракије, то се знало и на Божић, и на нову годину српску кад је оно како се зове Василије, и све смо ми увек, на Светог Саву, били велики свеци па смо подгрејали ракије. Е сад се ставља шећера - не ваља. А ја угрејем неки пут. Па шта да радим. Значи, иде њих неколико за тај бадњак и донесу и сви они буду ту? Јел то свака кућа пали, или? Па може свака кућа која донесе... Која донесе, а могу да се удруже па код једне куће да запале... Не, могу диду код иркве, тамо се запали, тамо седиду, Значи, ту дођу запале бадњаке, попију ракију, (...)

Кад изгоре бадњаци шта се онда ради? Па ништа, то изгори па после се баци, почисти... Јел се то носи у воће, јел се нешто ради са тим? У башmy. У башту се баци тај пепео? Jecme у бамmу.

- Божићна слама. Уношење сламе у кућу и њено растурање по свим просторијама обавља се на Бадњи дан увече. Сламу у кућу уноси домаћин 
заједно са децом. Пре него што унесу сламу опходи се око куће. Трећег дана Божића слама се односи(ла) у виноград да би се заштитио од временских непогода, али и да би боље родио.

Уношење сламе. ... и ондак треба слама да се донесе, онда газда од куће иде и се угреје овамо ракија и он иде одонуд, ко има децу иду за юим и вичу пију-квои, пију-квочз за юим, са юим да донесу сламе у собу да ставе... Значи, деда и деца излазе за сламу, (имате вашу сламу?) Па да, спремимо. Па пре смо имали нашу, како да нисмо имали... И онда иду, он иде напред и они иду за њим. Иду за юим, и онда баба угреје ракије и донесе деди и каже: Шта нам носиш? Живота и здравље и напретка у кућу и тако дође и деда стави свуд, неки пут пуно сламе. Деца се ваљаду. И после иду деца, сви чекаду да дођу да иду за сламу, цак сламе,... Јел се стављало нешто у сламу? Не, и после се мећали ораси и тако. А кад се уноси слама у кућу? E па на Бадюи дан, пре вечере. Пре вечере.

Вечера. А кад је обично вечера? Па тако, седам-осам сати, док не почну деца да иду да вичу по сокаку. Шта од пића има - ракија? Јел има вино? Има. То је било и раније, исто? Вина је било. Сокови? Није (Није било сокова?), није било сокова. Сад има.

- Бадюа вечера. За вечеру се припремају посна јела. Памти се да је вечера постављана на поду. Данас се једе на столу, раније се јело и на поду. За вечеру се спрема рибља чорба, пребранац, пржена свежа или сува риба, мед, крофне без јаја, штрудла, од воћа суве шљиве, ораси, од пића ракија и вино, а у новије време се користе и сокови. Осим што се ломе за јело, ораси се бацају у ћошкове просторије у којој се вечера. То раде домаћин или домаћица.

Припрема вечере. Кад се слама унесе, ... јел се постави вечера пре тога, или се унесе слама... Унесе, па се после вечера. То се спреми све и ондак се унесе слама и ондак се седне да вечера. Неко седне за сто да вечера, а неко раширу доле ... Јел има још увек да стављају на под? Сада не, а било је пре. До кад? Ми смо, свекар мој и свекрва су гор на сто, а ови су доле јели (комшије), јесте. На земљи. На земљи.

Ораси. Осим те хране јел било да се мед узима? Jecme, јесте, медораси се једу. После се не једу ораси, сутрадан на Божић. Не ваља због зуби, каже се поквару зуби. Па се склону. А на Бадюидан се једу. А јел се бацају у ћошкове ораси? Јесте, се ставе, пре вечере. Ко, домаћин? Јесте, домаћин. И како баца? Ко крста, ко (...) Одакле креће? Исток-запад... И шта говори? Да се буде живо и здраво, то дец̧а купу... Јел се бацају само та четири која иду у ћошкове, ништа се друго не баца? Разбиваду се, једу се... А ти који се баце у ћошкове колико стоје у ћошковима? Па деца одма бегаду, узму, кад оће, стојиду док се не почисти. А кад их почистите бацате их на ђубре или нешто радите са њима? Па ваљда поједу... А то кад се износи Божић износе се и ораси и онда се издвоје и поједу? Да, на Светог Стевана кад чистимо, 
скупимо сламу, ондак се ... Значи, ако их деца не поједу пре тога онда се сачисте...

Мед. А кажите ми мед кад се узима? Па на Бадюидан (Пре вечере?), пре вечере, јесте. Јел се узима нешто са медом? Ораси. Ораси и мед се узима? Зашто - због здравља, или? Због здравља. И онда се мало мажу гњезда на Божић с медом да кокошке лежиду, да не мош да је отераш...

Свећа. Да ли се пали свећа на Бадње вече? Jecme, се пали свећа и на Бадње вече и сутрадан на Божић. Да ли се пали једна свећа или су три као укрштене, или ...? Нема тога код нас. Једна свећа. Кад се пали, кад се гаси? Колико гори? Вечера кад се... Пред вечеру, док се вечера и онда се гаси? И ондак се гаси. Ко је гаси? Па, жена из куће, није газда баш, ко пређе тамо и угаси (Вином или прстима?). Па прстима, некад се вино на Свеца користило да се угаси.

Храна. Јел се увек користила виљушка, кашика, нож? Јел било да се нешто не користи на Бадњи дан? Не... Увек се прибор за јело користио? Да ли су ораси стављани у сито или су били само на столу у чинији? Па у нешто, у чинији било ... Кад се заврши вечера да ли храна остаје тамо где је била вечера или се склања? Па склонимо, после тог нема јела. Чак на Светог Стевана се узме пребранац... Значи на Бадње вече једете ту посну храну и кад завршите са јелом то се све склони. Све склони и ондак се једе сутрадан... Да ли се посуђе из ког се јело или се оставља са стране па се пере касније? Не, то се опере, а сутрадан не перемо судове - на први дан Божића. Значи на Бадњи дан се храна склони што се не поједе и опере се суђе из кога се јело? Јесте. А сутрадан кад се руча на Божић се првом једе супа и ринфлајш и ондак се криа (нејасно!) погача и кобасице се пржу,... Да ли је било да се према некој храни гледа каква ће бити година дал ће неко да се уда, дал ће неко да умре? Ја то незнам. То се знало пре. Стари знали много којешта. И кад је сат - нису имали сатове, и кад је све..., али сад нема. Знали су доба дана према сунцу? Јесте. И према сенции.

- Колиндање. Увече по обављеној вечери по селима крећу деца, али и старији, сами, по двоје или у групама од по њих неколико иду да посећују куће и пожеле срећу породици - да честитају празник. Кориндаши не улазе у кућу, већ само у двориште. Том приликом одрецитују или отпевају песмице намењене за ту прилику. Заузврат добијају ситније поклоне и / или нешто новца. Обично су им домаћице давале суве шљиве, јабуке, бомбоне или орасе. Поклоне су делили међу собом по завршетку обиласка села. Обично су певали:

„Ја сам мали чича Пера, / Ујела ме жута кера; / Кад претрчим преко мора, Дај ми, газдо, неки ора! Куј један, куј два, / То ћу све да примим ја!

Ако ј’ колач да чекамо, / Ако ј` жарач да бегамо!“ 
Опход деце. Да ли иду деца на Бадњи дан да честитају Бадњи дан и као их зовете (коринђаши?), или... Кориндају, јесте. Мало ми опишите како изгледају, ко иде? И велики и мали и юи четворо пет и двоје и по један долазу. Ево код нас сад да уђем и узмем орасе и бомбоне и ита још и неки леј да им дам сваким. Нико неће да дође за бадава, сваки воли да добије. Значи има више група које иду? Има и велики и мали и момции иили. Те новце после скупу па плату да се свира у дом на Божић, да играду. Јел иду још увек коринђаши, јел још увек коринђају? Иду, иду и сад... Јел су нешто обучени... Не, не... Обично. Обично су обучени, јесте. Шта им се даје - бомбоне, леј... Бомбоне, леј ... И кад дођу шта кажу? Јел улазе у сваку кућу? Ко није закључо капију уђу. Ко није закључо капију... А јел се дешава да неко закључа капију? O, па... Једно двоје троје вичу, а после закључаду. Кад дете дође гура на капију закључана капија. Ја увек имам кицељу једну, ставим ту орасе, видим колико су њи и тако дам свима и бомбоне и чоколаде ове - бананице те. И сваким дам по леј два, неки ко видим је пријатељ дам мало више. Јел стоје напољу ил улазе у кућу? Не унутра. Само напред. И шта кажу кад дођу? Незнам, заборавила сам како вичу: „Добро вече добри газдо ми смо дошли да јавимо данас нам се Христос роди у јаслици, у италиции“, ... не знам, заборавила сам, знам оно на послетку: ,ја сам мали чика Пера ујела ме жута кера ако колач да чекамо, ако жарач да бегамо “. А јел било раније, кад неће да их приме да им певају онако мало да их увреде? Није било. Није било. Значи кад неће да их приме они само оду даље... Није, сваки их прими. Ал они сад иду млого, преко више, неки пут сад један уђе други изађе, ... Само су ишли да коринђају, није било ништа друго? Није.

На Бадњи дан, докле се седи навече? Кад иду ови коринђаши? Па иду до десет, једанаест.

- Јелка. У селима је познат обичај кићења јелке. Појединци су знали да организују и посету „деда мраза“ само што је овде био обучен у дугачки кожух. Имао је такође и вештачку браду.

Кићење јелке. А јел било да се кити јелка? Било. Кад су почеле да се ките јелке? Кад су била децза мала смо китили још. Јел то после рата? После, шездесет... Већ шездесет и неке сте китили јелку? То су биле праве јелке, или... Праве јелке, не купљене. Из иуме. (...) Нисмо иили ми, се продавале. Могло је да се купи? Јесте. Чиме су се китиле јелке? Па биле кристинке(?) Шта је било? Кристинке - бомбоне у фолији и било је ... ти мали ако си нашо, нашли смо негде, није било да се купи али негде смо нашли смо ишли негде даље... Куповали сте накит, а јел било да су се јабуке качиле? Било и јабуке и ораси увијали у злато и све, било... То било код вас. Јел било и другде или сте само ви тако китили? Ма и други су... Куповали јелке... Јесте, а после смо куповали и оне да гориду... А, оне сијаличице... Да, а били и фењерчићи, тако па после то изгорело па посе смо куповали тако оне ито сјају што стављају сад на Нову годину на пут да се сјаји. Било је, смо правили увек... 
Деда мраз. Се оправи неко деда мраз, донесе децама и пита дал слушају, дал имају ... Јел се то радило за Нову годину? На Божић, нисмо то радили за Нову годину, за Божић. За Нову годину то сад се прави ваљда... Нисмо. Ми смо за Божић. За Божић. Ко је - неко из куће био деда мраз? Да из куће или дође неко са стране. Јел то наручите или он дође сам? Па не, знамо ко ће да дође, ми кажемо да дође... ... да буде деда мраз. Јел буде прави деда мраз? Обуче се баш као деда мраз? Па обуче се, стави фату ту, били они кожуси они до доле ... Нису били у црвеном, него су били одевени у кожусима? У кожусима то се обуче и капу на главу и то се напуни фата, онога белога и тако је било. И доносе поклоне деци? То ви купите и њему дате да он донесе? Да. Као божић бата донео поклон. Слушало је дете слушало и он му да поклон. Јесу се деца радовала? Како да не, нису знали они да није то деда мраз, ... Нису, веровали су... Ја сам сакрила то и правила тамо да не види нико и ондак кад је то угасимо све сијалице и носи деда тој... А шта сте обично спремали као поклон деци? Па шта је било, ита је било да купиш то... није било богзна шта пре, се радовала деца... Ви кад сте били мали није вам долазио деда мраз (Hије), то сте ви вашој деци спремали. До кад сте им то правили да долази деда мраз? Нису били велики кад су сазнали да деда мраз није деда мраз. Ишли су у школу или на факултет? Иили су у школу, нису на факултет. И онда више нису хтели? Нису. Јесу били разочарани? Нису. Били велики и ондак нису. Није више било лепо. Јесте.

Идење на гробље. А да ли се иде на гробље (...) око Божића? Иде се на гробље. Кад? На Бадњи дан. На Бадњи дан се иде? После подне на Бадњи дан се ишло на гробље. Иде се на гробље, није било да се не иде. Ко може, ко стигне тај иде или деца отидну или... Само се запале свеће или се нешто носи? Па ете то колач се оправи, кад правиш оне законе правиш и колач један мали за гробље. Прави се један мали за гробље. И то се оставља тамо или се враћа кући? Па се враћа кући. Сад нема ко, даш неким сиротим ко знаш да нема, нема другим да даш. Овако... Сви иду ондак на гробље, сви на Бадњи дан, и на Дуовску суботу сви идеду на гробље.

$$
* * *
$$

Божић. Божић се празнује три дана. Спада у најужи круг најзначајнијих народно-хришћанских светковина. Срби су задржали, као и Српска православна црква, Јулијански календар - Божић славе 7. јануара.

Најважнији и најсвечанији је први дан Божића када се одлази у Цркву, пече печење, меси чесница, припрема божићни ручак, реже божићни колач. Домаћица обавља радње око божићног ручка и припреме чеснице, а домаћин обично одлази у цркву на јутарњу службу. Ујутру на Божић се поједе нешто од мрсне хране или се то обавља по повратку са јутарње службе или тек за ручак. На дан Божића се гледало какво је време и према томе се одређивало каква ће бити година. 
- Одлазак у цркву. На први дан Божића неко од укућана одлази у цркву на Јутрење и причест. Домаћица обично остаје код куће да припреми чесницу.

Јутрење. Кад се обично устаје на Божић? Па ујутру се иде у иркву кој оће да носи свеће. У седам почиње јутрење. Пре него се пође у цркву да ли се нешто ради, да ли се нешто узима од хране, да ли се нешто припрема? ... Ништа. Не, не.

- Чесница. Као што се на Бадњи дан месе фигурални хлебови за здравље чланова домаћинства, плодност стоке и родност поља, на Божић се у исту сврху припрема чесница која представља врсту погаче. Обавезно се у њу ставља метални новац. Ко од укућана пронађе новац у чесници веровало се да ће бити срећан те године. Чесница се ломи пред ручак. Комаде чеснице домаћин даје укућанима по старешинству, а може комаде намењивати и умрлим члановима породице као и путнику намернику.

Да ли се прави чесница? Ко прави и када? Прави онај што не иде у цркву, онај што остане кући тај прави чесницу... Како се прави чесница: јел се слаже са орасима или се прави од пројиног брашна? Од брашна овог чистога се прави. Од пшеничног брашна? Јесте, се испече тако погача. Нека, сад се бации и мало квасца, мало мекша, то се правило пре ништа се није ставило (била бесквасна?). Јесте, и тако се правило, се стави леј. Где се стави? Унутра. Унутра. И ондак на Божић се испече, На Божић печемо. Јел се она премазује... С медом. С медом? А јел се бушка? Мало да, сасвим сас виљуиком. Сас виљушком, добро? И то се ондак се кида. Кад се испржу овамо кобасице. И кобасице и првом погача се једу. А чесница, да ли се ујутру захвата вода из бунара за прављење чеснице? Jесте, па да, из бунара. Онај ко захвата воду из бунара јел нешто говори ...Нема... Ништа. Није било ни раније? Не, није било.

- Божићни ручак. За божићни ручак припрема се обично: говеђа или пилећа супа, месо из супе, сос (обично од парадајза), кромпир, живинско или говеђе кувано месо, сарма и неко печење, а од посластица разни колачи.

Пре него се пође у цркву да ли се нешто ради, да ли се нешто узима од хране, да ли се нешто припрема? Ништа. Не, не. Ништа док се не врати из цркве? Има неко, ако гори шпорет престави сарму или нешто друго ако није скуво пре један дан. То је зима па стоји. Значи, сарма за Божић може да се скува и пре Божића. Па, на Бадюи дан кад се кува. Не може баш све да се стигне да се испече печење и све.

Печење. А кад се пече печење? Па то је било тако на тај дан - на Божић, а сад печеду пре. Значи, печење се пекло баш на сам дан Божића? Где се пекло печење. Па, у шпорету. Нисмо ми оно на ражањ, нисмо, то Клисуричи, они и овце праву на ражањ. Нисмо на... Значи, закоље се на Бадњи дан (И пре се закоље) и пре Бадњег дана? Јесте и ондак се испече на Бадњи дан и ондак. Онда се кува супа и спрема, колачи се праве пре или торте ко оће. 
Посета цркви. Ко иде на јутарњу службу у цркву? Па, газда. Мој свекар је ишо. После идем ја на јутрење и носи...

Свећа. Не носим, купим тамо свећу и дам за здравље и купим да донесем кући кад се пререже колач ко није купио пре. Већином купимо пре па доносимо кући. Шта? Свећу? Свећу. Не гори иста свећа која је горела на Бадњи дан? Не, друга свећа се купује. Друга свећа. Једна се пали у иркву за здравље, а једна се пали на Божић. А кад се та пали [у цркви] не пали се мртвима, само живима? Само живима.

Ручак. Значи, иде се у цркву, домаћица остаје код куће да то припреми, кад се дође с из цркве... Она која остане кући та скува и спреми све... Спреми ту као чесницу... и онда... Ручак... Одма ручак. Ручак - код нас има супа, ринфлајш, месо - барено, такој има и код ови Војвођани, они имају ... Супа, сос, месо! Јесте, имају ко пос печење, али прво кад се то супа, ринфлаји се поје,...

Чесница. ... Онда се кида [чесница] једним и другим и трећим. И после сви гледаду дал је леј испао код њи, и кући, после... Јел то буде после дванест или пре дванест? После. После дванест? И на кућу се да и путнику намернику, и сваким у кући. То што се намењује кући и путнику намернику - где то стоји и шта се ради са тим? То се поје, кад није код њега леј онда се nоједе, па да.

Доручак. Да ли се доручкује на Божић? Пре су доручковали стари. Кад су се јеле пржене кобасице? Па то се на Божић мало у подне мало узме, јесте и док је неко доручковао, неко не кува - не праву доручак, ручак на Божић. Пре се доручковало, морали ти стари да једу, нема то. То је било кад су они постили па као да промрсе? Да, да. Промрсивали су са кобасицама? Да, да. Само су јели кобасице, ништа друго? Кобасище, леба, иигерище сас луком, шунка се обари па се испржи мало... Јел се то јело пре него што се крене у цркву? Да, да...

Ручак. Ондак се руча оно што се спремило за ручак? Кад се дође ондак се руча. Кад се сече колач божићни? Па тако кад стигнеш на печење. Исто кад се стигне на печење. А кад се пали свећа? Ондак. Исто и то. То ради домаћин? Домаћица која је ту, упали свећу и ондак се пререже колач. Ко реже колач? Ко оће - деца режу сад. Дигнемо мога сина, ајде ти и сестра нека реже с тобом и тако се пререже.

Печење. Шта је печење за Божић? Шта може да буде? Па шта може прасеће, ћуреће се испече од ћурке, нема јагњеће, то сад има јагњеће, само прасеће, свиғско месо кад се закоље се остави и се испече. Јел се то зове печеница, или... како се зове то печење? Па, печење, ми кажемо печење. Да ли се неки комад печења оставља за Мали Божић - за четрнаести. За Нову годину? За Нову годину. Да. Не, не. Може се остави непечено. Остави се 
непечено, па се онда пече за Нову годину. Да за Нову годину, јесте. И за Богојављење, посе. То су били ти свеции. Сви смо славили.

Бунар. Да ли је било, пошто имате бунар у дворишту, да ли је било да се иде на бунар ујутро рано да се посипа житом и да се честита води Божић? То кад идемо на Богојављење за свету водии, ондак сипамо водице мало у бунар. Само тада. Није се ишло... Није ...

Трећи дан Божића. На овај дан се празнује Свети Стеван и износи Божић из куће. То ради домаћица која ујутру рано почисти собе. Слама се носи у виноград. То раде домаћини свечано и на коњима. По повратку из винограда обилазе око села, а кад се врате у село препуштају се дружењу.

Колико се слави Божић - три дана? Три дана. Да ли се трећег дана ишло код кума у посету, јел се носило нешто или су долазили кумови? $\mathrm{He}$. Код нас на Покладе. Шта се ради са костима од печења од Божића - дал се сакупљају? Где се бацају? Шта се ради са њима? Па, не знам. Давали смо nсима да једу. Кад износите Божић? Кад се чисти Божић? На трећи дан - на Светог Стевана. Кад - објасните мало? Па ујутру кад се жена дигне мора све да почисти и то се ондак све веже,...

Слама. ... Се однесе мало, носили пре у виноград. Узму коње, узјашу коюе и однесу у виноград, однесу ту сламу да роди гројзе да роди ... Где стављају у винограду? На лозу. На једну лозу грудву или распореде... Па можеш на две три... ставља се на лозу. Што су ишли на коњима? Јел су виногради били далеко? Далеко. Јел то ишо свако у свој виноград или се скупе више... Свако у свој. Њих више, свако узјаше свог коња стави ћилим на коња и јашу и ондак пију, иду око села. То је било пре. И сад неко се вози с колима. Ко иде око села? Шта раде око села? С коњима око села се прату. Јашу коњ ако села, ту има код нас се види около како се иде. И ту иде, јашу коюе, иду у виноград и ондак дођу и пију и сви зајно здружу... Слама се носи у виноград? А оно ђубре... То се стави на ђубре.

Метла. А метла с којом се чисти, шта се ради с њом? Нема то, не знам, сад има ове господске метле ... Не бацате је, остављате је у кући и даље? Да.

$$
* * *
$$

Нова година, Свети Василије. Нова година се прославља више као породични празник тако да нема значајније комуникације са суседима и другим сељанима на тај дан. Прослављање је готово идентично као и божићно с тим што се за Нову годину месе мали хлепчићи - мрсуљице које једу само укућани.

За Нову годину јел има неких обичаја? Се иде у иркву и се месе оне „мрсуљице“ како су се звале. Како се то меси? Сас квасиом, па се узме 
слама, тако три сламе и се забоду и се прави округле, те мрсуљице, три ... Једна се прави? Три, три. Па да имамо сви да јемо. Па тако се забоде на три места и се испече. Да ли се те сламке увезују црвеним концем? Не. Само се држе у руци? У руции се држе и то се пробуши. То је исто пшенично брашно? Јесте. Са квасцем или без квасца? Са квасием. И то се једе за ручак? Да. Јел се премазују медом. Па нису, ја мислим, само онако... На чеснииу смо стављали мед, а нисмо ... се пржи нешто ујутру и опет шунке. То се рано месило док су сви у кући, док нико није отишо у иркву, то се јело за доручак, за ручак ако остане то се је, али се за фруштук... А шта се за ручак спремало? Све по реду. Исто се спремало као за Божић? Да. Ништа се од Божића није остављало за Нову годину, све се поново спремало? Па поново супа, друга кокошка на супу, ко има то свиюско, ко нема од кокошке испече тамо у рерну, то било све...

$$
* * *
$$

Резултати истраживања у Соколовцу - једном од пољадијских села који су мањем обиму изложени у овој прилици указују на очуваност обичаја као и структуру прослављања код српског становништва у овом делу Румуније. Одређене сличности постоје са прослављањем Божића код Срба у другим селима која су посећена ради истраживања а смештена су у различитим деловима Румуније (Дунавска Клисура, Горњи Банат, Доњи Банат, Банатска Црна Гора), али и у Војводини - првенствено у војвођанском Банату (називи божићних хлебова, опходи деце и сл.), а што је свакако тема за посебну врсту рада и истраживања. ${ }^{4}$

\section{Извори и литература}

Ивановић Баришић, Милина. Теренска грађа, 2019: Соколовац.

$*$

Ивановић Баришић, 2018: М. Ивановић Баришић, „Божић код Срба у Банатској Клисури“. Исходишта (4): 89-98.

Ивановић Баришић, 2018: М. Ивановић Баришић, „Божић код Срба у Румунији - Краљевац и Чанад“. Исходишта (5): 129-144.

\footnotetext{
${ }^{4}$ Изражавам неизмерну захвалност свим казивачима из Соколовца: Даници Белодедић, Животи Белодедић и Даница Влајић, који су издвојили своје време да би га посветили разговору о Крсној слави, Божићу и свадби. Такође, захвалност и возачу Милету на помоћи и стрпљивом целодневном чекању да екипу врати у Стару Молдаву где је била смештена.
} 
Milina Ivanović Barišić

\section{CHRISTMAS IN SERBIAN TRADITION IN SOKOLOVAC - ROMANIA}

\section{Summary}

In June 2019, I stayed a few days in Romania - Poljadia, where I was doing research on the topic of Patron Saint and Christmas, as a participant of the project: The research of the history and culture of Serbs in Romania, organized by the Science Centre at the Union of Serbs in Romania (Timisoara). On this occasion, I visited three villages: Sokolovac, Lugovet and Zlatica. The statement will present the initial findings of the preservation of the Christmas customs of the Serbs in village Sokolovac.

Key words: Christmas, customs, Serbs, Sokolovac, Romania. 